\title{
In situ localization of Chlamydia trachomatis and Chlamydial Heat Shock Protein 60 in Endometrial Curettage Tissue of Recurrent Spontaneous Aborters
}

\section{Sangita Rastogi $i^{*}$, Chanchal Yadav ${ }^{1}$ and Banashree Das ${ }^{2}$}

${ }^{1}$ Microbiology Laboratory, National Institute of Pathology (ICMR), Sriramachari Bhawan, Safdarjung Hospital Campus, Post Box No. 4909, New Delhi-110029, India

${ }^{2}$ Department of Obstetrics and Gynecology, Vardhman Mahavir Medical College and Safdarjung Hospital, New Delhi-110029, India

"Corresponding author: Dr. Sangita Rastogi, Microbiology Laboratory, National Institute of Pathology (ICMR), Sriramachari Bhawan, Safdarjung Hospital Campus, Post Box No. 4909, New Delhi-110029, India, Tel: +91-09810217260; E-mail: rastogi_sangita@rediffmail.com

Received date: Aug 24, 2015; Accepted date: Sep 08, 2015; Published date: Sep 10, 2015

Copyright: (C 2015 Rastogi S, et al. This is an open-access article distributed under the terms of the Creative Commons Attribution License, which permits unrestricted use, distribution, and reproduction in any medium, provided the original author and source are credited.

\section{Description}

In India, genital infection with Chlamydia trachomatis is a major health problem in women because of high prevalence (upto $81 \%$ ). During pregnancy, chlamydial infection may cause various perinatal complications including spontaneous abortion $[1,2]$.

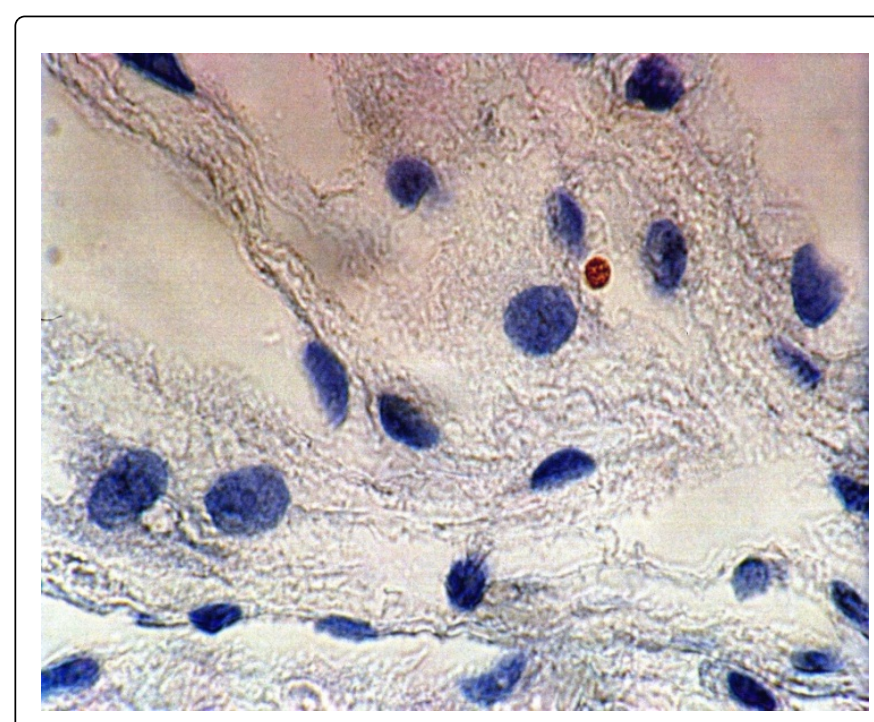

Figure 1: In situ localization of elementary body of Chlamydia trachomatis in the endometrial curettage tissue from patient undergoing recurrent spontaneous abortion (400X).

Also, immunity to chlamydial heat shock protein 60 (chsp60) is associated with upper genital-tract infection and presence of chsp60 may regulate process of abortion by stimulating macrophage function [2]. Hence, aim of this study was to investigate whether C. trachomatis is associated with spontaneous abortion in patients with prior history of three or more spontaneous abortions, viz.: Recurrent Aborters (RA). We used immunohistochemical approach to localize chlamydial infection within the endometrial curettage tissue (ECT) in women with spontaneous abortion. Immunohistochemical analysis confirmed $C$. trachomatis in ECT (11/ 100) (Figure 1). Also, double staining was done for in situ localization of macrophages (CD 68) and chsp60 (within the macrophages) in ECT (Figure 2). chsp60 was co-localized within macrophages in (72.7\%) infected RA. Serum level of IgG antibodies to chlamydial heat shock protein-60 (chsp60) was determined by using commercial kit as per manufacturer's recommendations (Medac, Germany). Among the Chlamydia-positive RA, 63.6\% (7 of 11) showed presence of serum chsp60 antibodies. Results suggest definite need for $C$. trachomatis screening in women experiencing spontaneous abortion to prevent recurrent miscarriage.

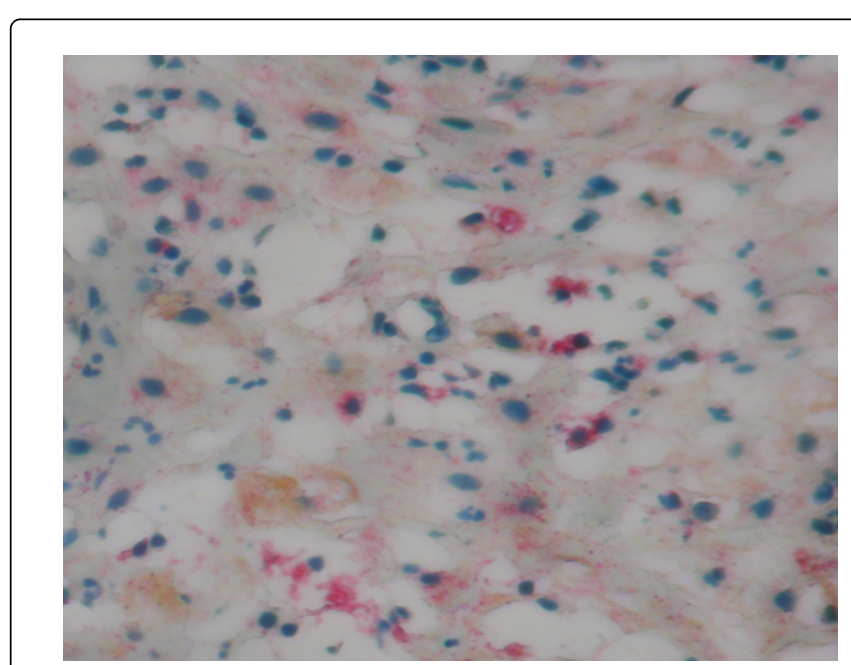

Figure 2: Dual staining for chlamydial heat shock protein 60 (red colour) and macrophages (CD 68; brown colour) in the endometrial curettage tissue from Chlamydia trachomatis-infected patient experiencing recurrent spontaneous abortion (200X).

\section{Acknowledgements}

This work was supported by research project grant from Life Sciences Research Board, Defence Research \& Development Organization, Government of India, New Delhi, India.

\section{References}

1. Singh N, Prasad P, Kumar P, Singh LC, Das B, et al. (2015) Does aberrant expression of cyclooxygenase- 2 and prostaglandin-E2 receptor genes lead to abortion in Chlamydia trachomatis-infected women. J Matern Fetal Neonatal Med 25: 1-6.

2. Askienazy-Elbhar M (1996) Immune consequences of Chlamydia infections in pregnancy and in vitro fertilization outcome. Infect Dis Obstet Gynecol 4: 143-148. 